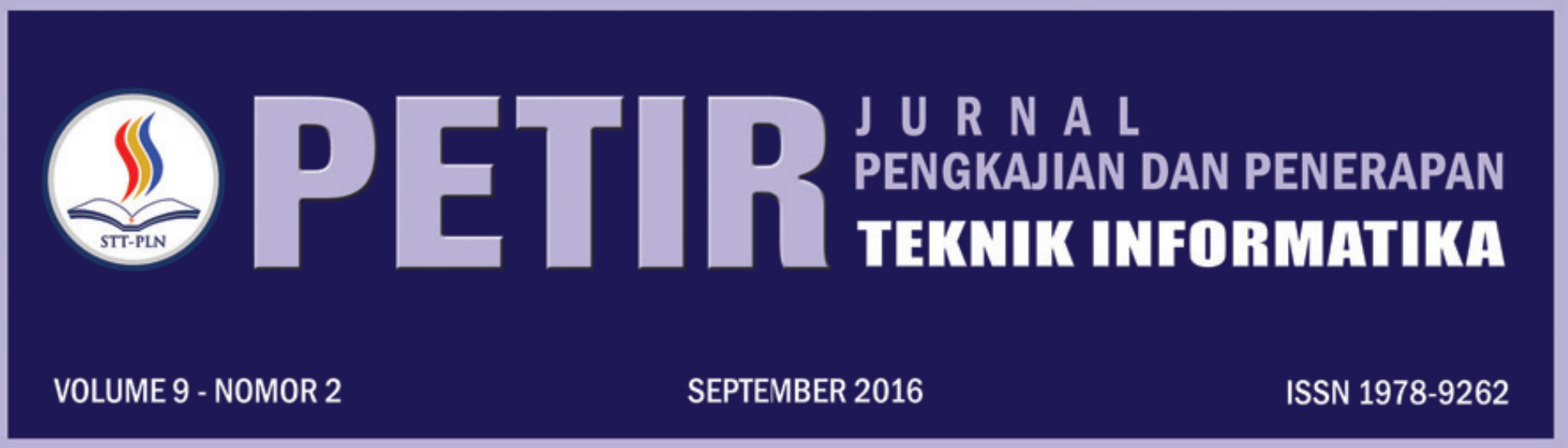

ANALISA SPASIAL UNTUK MELIHAT TINGKAT KESEJAHTERAAN MASYARAKAT DI PROVINSI BANTEN Muhamad Jafar Elly; Reza Pahlevi

PENENTUAN WILAYAH RAWAN PENYAKIT BERBASIS LINGKUNGAN DI JAKARTA TIMUR MENGGUNAKAN SISTEM INFORMASI GEOGRAFIS

Atiqah Meutia Hilda; Muhamad Jafar Elly; Windu Nugroho Cahyo Pamungkas

APLIKASI PENCARIAN USTADZ UNTUK WILAYAH DKI JAKARTA MENGGUNAKAN ALGORITMA HAVERSINE FORMULA BERBASIS ANDROID

Harni Kusniyati; Haries Fadhillah

PERENCANAAN ARSITEKTUR ENTERPRISE PERGURUAN TINGGI DENGAN PENDEKATAAN ENTERPRISE ARCHITECTURE PLANNING (EAP) (STUDI KASUS POLITEKNIK PIKSI GANESHA)

M. Farid Rifai

PERANCANGAN E-KATALOG PADA PERPUSTAKAAN DIGITAL STT-PLN BERBASIS WEB

Yessy Fitriani; Yasni Djamain; Risalatulina Dwi Kurniati

APLIKASI SISTEM GPS KEGIATAN OPERASIONAL PERSAMPAHAN DINAS PENGELOLAAN SAMPAH, PERTAMANAN DAN PEMAKAMAN (DP4) KOTA SUKABUMI

Yasmi Afrizal; Julian Chandra W
PERANCANGAN APLIKASI PENGOLAHAN DATA KAS BERBASIS ONLINE
(STUDI KASUS : KEMENTRIAN ' $X$ ')
Dian Hartanti; Lingga Desyanita

PERANCANGAN SISTEM INFORMASI PESERTA SERTIFIKASI

(Studi kasus LSP Piksi Ganesha)

Hendra Jatnika

RANCANG BANGUN APLIKASI SEC-WAY GUNA PENGINGAT BEPERGIAN DILENGKAPI INFO CUACA DAN CCTV JALAN RAYA LOKASI PILIHAN BERBASIS ANDROID STUDI KASUS DKI JAKARTA

Yasni Djamain; Intan Ratna Sari Yanti; Hari Wibowo

PREDIKSI PENERIMAAN SISWA BARU PADA MADRASAH ALIYAH AS-SAYAFI'IYAH 02 MENGGUNAKAN METODE TIME SERIES

Sarwo; Hermawan

PERANCANGAN SIMULASI MEDIA PEMBELAJARAN DENGAN METODE DIVISION REMAINDER UNTUK PENCARIAN ALAMAT RELATIF PADA PROSES PENEMPATAN DATA

Dewi Arianti Wulandari; Darma Rusjdi

ANALISIS SISTEM PENENTUAN LOKASI GANGGUAN JARINGAN DISTRIBUSI LISTRIK TERINTEGRASI GOOGLE MAP Abdul Haris; Herman Bedi Agtriadi

\begin{tabular}{|c|c|c|c|c|c|c|}
\hline \multirow{2}{*}{$\begin{array}{c}\text { ISSN } \\
|||||||||||||||||||||||||| \mid\end{array}$} & \multicolumn{6}{|c|}{ SEKOLAH TINGGI TEKNIK - PLN (STT-PLN) } \\
\hline & PETIR & VOL. 9 & NO. 2 & HAL. $89-166$ & JAKARTA, SEPTEMBER 2016 & ISSN 1978-9262 \\
\hline
\end{tabular}




\title{
PERENCANAAN ARSITEKTUR ENTERPRISE PERGURUAN TINGGI DENGAN PENDEKATAAN ENTERPRISE ARCHITECTURE PLANNING (EAP) (STUDI KASUS POLITEKNIK PIKSI GANESHA)
}

\author{
M. Farid Rifai \\ Teknik Informatika - Sekolah Tinggi Teknik PLN
}

\begin{abstract}
Strategy and policy in an organization that profit oriented also have social mission (public service) that major at consumer service. Information system Growth and Information Technology will affect to competition that growing competitive, this condition goes into effect also in the world of education especially for college that managed by society (private sector), claim the party of organizer to develop and develop information system in helping actifity business, reach organization target and service for stake holder especially related to data, information, technology and application. This Development and information system development must in harmony with instruct organization strategy (enterprise), found such cases of information system management experiences of failure in achieving target (objective) this organization because utilization disagree with college purpose and direction (organization).

Enterprise Architecture Planning (EAP) as method or frame of reference to develop an information architecture. EAP is an architecture planning methods that orientation at business need that consist of data architecture, application and technology and implementation planning from architecture that has been made to support business activity to attainment of organization mission. EAP explains data architecture, application and technology that required to support organization business. Much developments IS experience of failure because need development IS are made base certain need without planning beforehand.

Politeknik Piksi Ganesha, as one of higher education organizer that managed by private sector have strong comitment for information system utilization to support its business activity until must plan architecture enterprise. Architecture enterprise that will be modeled at Politeknik Piksi Ganesha, consist of : Data Architecture, Application, Technology Architecture, Roadmap implementation plan..

Architecture enterprise modeling relate to processes that already commonly use in business higher education management in Politeknik Piksi Ganesha Bandung, where as discussion scope is limited at area Academic, area Administrations and Finance, area HRD and General.
\end{abstract}

Keyword : information system, enterprise architecture planning (EAP), data architecture, application architecture, technology architecture

\begin{abstract}
Abstrak
Strategi dan kebijakan dalam suatu organisasi yang profit oriented juga mempunyai misi sosial (public service) yang mengutamakan pada layanan konsumen. Perkembangan sistem informasi dan teknologi informasi akan berdampak pada persaingan yang semakin kompetitif, hal ini berlaku juga di dunia pendidikan terutama bagi perguruan tinggi yang dikelola oleh masyarakat (swasta), menuntut pihak pengelola untuk membangun dan mengembangkan sistem informasi dalam membantu aktifitas bisnis, mencapai tujuan organisasi dan layanan bagi stake holder terutama yang berhubungan dengan data, informasi, teknologi dan aplikasi. Pembangunan dan pengembangan sistem informasi ini harus selaras dengan arah strategi organisasi (enterprise), ditemukan beberapa kasus pengelolaan sistem informasi mengalami kegagalan dalam mencapai tujuan (objective) organisasi karena pemanfaatan ini tidak sesuai dengan arah dan tujuan perguruan tinggi (organisasi).

Enterprise Architecture Planning (EAP) sebagai salah satu metoda atau kerangka acuan untuk membangun sebuah arsitektur enterprise. EAP merupakan suatu metode perencanaan arsitektur yang berorientasi pada kebutuhan bisnis yang terdiri dari arsitektur data, aplikasi dan teknologi serta rencana implementasi dari arsitektur yang telah dibuat untuk mendukung aktivitas bisnis demi pencapaian misi organisasi. EAP menjelaskan arsitektur data, aplikasi dan teknologi yang dibutuhkan untuk mendukung bisnis organisasi. Banyak pengembangan IS mengalami kegagalan karena pengembangan kebutuhan IS dibuat berdasarkan kebutuhan tertentu tanpa ada perencanaan terlebih dahulu.

Politeknik Piksi Ganesha, sebagai salah satu penyelenggara pendidikan tinggi yang dikelola oleh swasta memiliki komitmen yang kuat terhadap pemanfaatan sistem informasi untuk mendukung aktivitas bisnisnya sehingga perlu merencanakan arsitektur enterprise. Arsitektur enterprise yang akan dimodelkan pada Politeknik Piksi Ganesha, meliputi : Arsitektur data, Aplikasi, Arsitektur teknologi, Rencana implementasi.

Pemodelan arsitektur enterprise mengacu kepada proses-proses yang sudah biasa digunakan dalam bisnis penyelenggaraan pendidikan tinggi di Politeknik Piksi Ganesha, sedangkan ruang lingkup pembahasan dibatasi pada bidang Akademik, bidang Administrasi dan Keuangan, bidang SDM dan Umum.
\end{abstract}

Kata Kunci : information system, enterprise unified process (EAP), arsitektur data, arsitektur aplikasi, arsitektur teknologi. 


\section{Pendahuluan}

Seiring dengan perkembangan teknologi informasi yang sangat pesat memberikan dampak terhadap kegiatan-kegiatan perusahaan maupun instansi-instansi dalam rangka meningkatkan kinerja organisasi, khususnya dalam dunia pendidikan perkembangan infrastruktur teknologi informasi dijadikan sebagai alat bantu operasional dan penentu kebijakan bagi pihak manajemen. Persaingan yang semakin kompetitif dalam dunia pendidikan terutama bagi Akademik yang dikelola oleh masyarakat (swasta), menuntut pihak pengelola untuk mengembangkan atau membangun dalam membantu aktifitas bisnis untuk mencapai tujuan organisasi dan sebagai layanan bagi stake holder terutama yang berhubungan dengan data, informasi, teknologi dan aplikasi.

Perencanaan, pengembangan, dan pengelolaan Information System (IS) ini harus selaras dan sesuai dengan arah strategi organisasi (enterprise), banyak kasus pengelolaan sistem informasi mengalami kegagalan dalam mencapai sasaran (objective) organisasi karena pemanfaatan ini berjalan tidak sesuai dengan arah dan tujuan serta kebutuhan Akademik (organisasi).

Politeknik Piksi Ganesha, sebagai salah satu lembaga penyelenggara pendidikan tinggi mengimplementasikan pemanfaatan IS guna menambah pengetahuan terhadapan disiplin ilmu yang digeluti dan juga sebagai bentuk layanan kepada mahasiswa, dosen dan stakeholder. Pemanfaatan IS saat ini dirasakan belum optimal dalam mendukung bisnis organisasi, keselarasan penerapan IS dengan kebutuhan organisasi hanya mampu dijawab dengan memperhatikan faktor integrasi didalam perencaan, pengembangan, dan pengelolaannya, tujuan integrasi yang sebenarnya adalah untuk mengurangi kesenjangan yang terjadi dalam proses pengembangan sistem. Untuk menurunkan kesenjangan tersebut, maka diperlukanlah sebuah paradigma dalam merencanakan, merancang, dan mengelola IS dengan pendekatan Enterprise Architecture Planning (EAP).

\section{Landasan Teori}

\subsection{Enterprise}

Enterprise umumnya sering disamakan dengan pengertian organisasi atau perusahaan. Beberapa definisi tentang enterprise antara lain dinyatakan sebagai berikut:

1. Setiap aktivitas yang memiliki suatu tujuan tertentu (Software Engineering Institute, www.sei.org);

2. Tiap kumpulan organisasi yang memiliki beberapa tujuan/prinsip umum, dan/atausuatu garis dasar. Dalam pengertian ini enterprise dapat berupa korporasi, divisi dari suatu korporasi, organisasi pemerintah, departemen tunggal, atau suatu jaringan organisasi dengan geografis yang berbeda yang dikaitkan dengan tujuan tertentu (Electronic Industry Assocation, 2008)
3. Organisasi atau badan lintas organisasi yang mendukung lingkup bisnis dan misi yang telah ditetapkan (Spewak, 1992).

\subsection{Arsitektur (Architecture)}

Beberapa definisi tentang arsitektur menyatakan sebagai berikut:

1. Arsitektur (Architecture) merupakan komponen-komponen sebuah sistem yang terdiri dari jaringan, perangkat keras dan lunak yang distrukturkan. (Electronic Industry Assocation, 2008)

2. Rancangan keseluruhan jenis konstruksi baik fisik maupun konteks, nyata atau maya. $(\mathrm{ICH}$ Architecture Resource Center, 2008)

\subsection{Arsitektur Enterprise (Enterprise Architecture [EA])}

Arsitektur Enterprise, yang merupakan salah satu disiplin dalam sistem informasi memiliki definisi sebagai berikut:

1. Pendekatan logis, komprehensif, dan holistik untuk merancang dan mengimplementasikan sistem dan komponen sistem yang bersama (Parizeau, 2002).

2. Cetak biru pemetaan hubungan antar komponen dan semua orang yang bekerja di dalam perusahaan secara konsisten untuk meningkatkan kerja sama/kolaborasi, serta koordinasi diantaranya (Ward, John and Peppard, Joe, 2002).

3. $E A$ adalah deskripsi dari misi stakeholder yang di dalamnya termasuk informasi, fungsionalitas/kegunaan, lokasi organisasi dan parameter kinerja. EA mengambarkan rencana untuk mengembangkan sebuah sistem atau sekumpulan system (Osvalds, 2001).

\subsection{Enterprise Architecture Planning (EAP)}

EAP merupakan metoda yang digunakan untuk membangun arsitektur informasi. Menurut Steven H Spewak, EAP merupakan pendefinisian bisnis dan arsitektur, bukan perancangan bisnis dan arsitekturnya. Perencanaan Arsitektur Enterprise (EAP) merupakan proses mendefinisikan arsitektur-arsitektur untuk penggunaan informasi yang mendukung bisnis dan juga mencakup rencana untuk mengimplementasikan arsitektur tersebut.

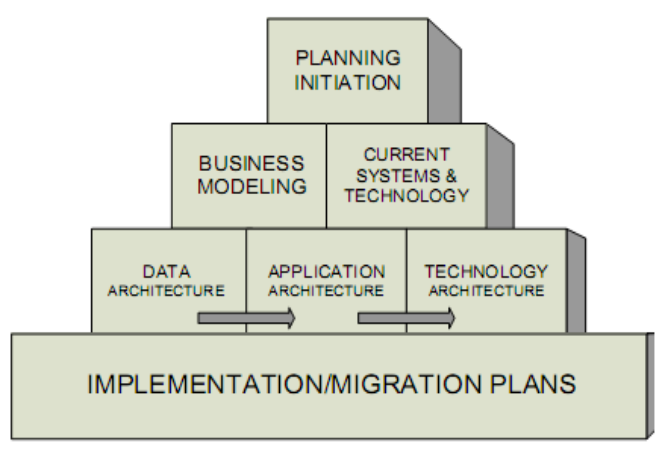

Gambar 2.1 Layer EAP (Spewak, 1992) 


\subsection{Value Chain Michael E. Porter}

Fungsi dari value added chain, menurut Michael E. Porter yaitu untuk mendeskripsikan cara melihat bisnis sebagai rantai aktifitas yang mengubah input menjadi output sehingga memilik nilai bagi pelanggan (Porter, E Michael, 1985) seperti pada Gambar 2.3 Value added chain dibawah ini :.

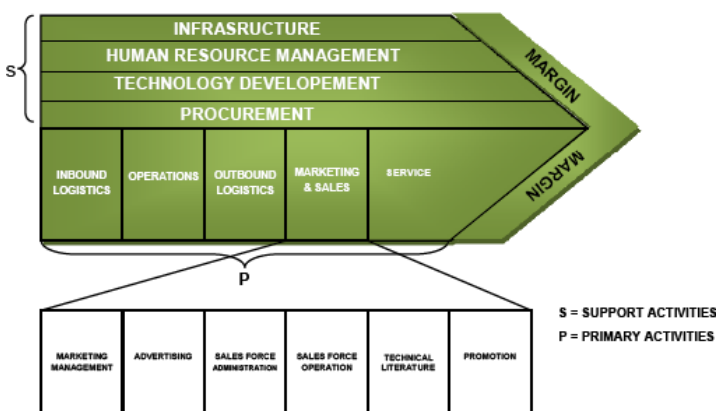

Gambar 2.2 Value added chain Michael E. Porter yaitu:

Value chain membagi dalam dua kategori,

1. Primary activities, (line functions) merupakan aktifitas utama dari organisasi yang melibatkan aktifitas-aktifitas sebagai berikut:

2. Inbound Logistics, pada bagian ini terkait dengan penerimaan, penyimpanan, dan pendistribusian input menjadi produk.

3. Operations, semua aktifitas yang terkait dengan pengubahan input menjadi bentuk akhir dari produk, seperti produksi, pembuatan, pemaketan, perawatan peralatan, fasilitas, operasi, jaminan kualitas, proteksi terhadap lingkungan.

4. Outbond Logistics, aktifitas yang terkait dengan pengumpulan, penyimpanan, distribusi secara fisik atau pelayanan terhadap pelanggan.

5. Marketing and Sales, aktifitas yang terkait dengan pembelian produk dan layanan oleh pengguna dan mendorong untuk dapat membeli produk yang dibuat. Memiliki rantai nilai khusus, antara lain :
a. Marketing management
b. Advertising
c. Sales force administration
d. Sales force operations
e. Technical literature
f. Promotion

6. Service, aktifitas yang terkait dengan penyediaan layanan untuk meningkatkan atau merawat nilai dari suatu produk, seperti instalasi, perbaikan, pelatihan, suplai bahan, perawatan dan perbaikan bimbingan teknis.

7. Secondary activities, (staff atau fungsi overhead) merupakan aktifitas pendukung yang membantu aktifitas utama. Secondary activities melibatkan beberapa bagian/fungsi, antara lain:

8. Firm infrastructure, merupakan aktifitas, biaya, dan aset yang berhubungan dengan manajemen umum, accounting, keuangan, keamanan dan keselamatan sistem informasi, serta fungsi lainnya.
9. Human Resources Management, terdiri dari aktifitas yang terlibat seperti penerimaan, dengar pendapat, pelatihan, pengembangan, dan kompensasi untuk semua tipe personil, dan mengembangkan tingkat keahlian pekerja.

10. Research, Technology, and System Development, aktifitas yang terkait dengan biaya yang berhubungan dengan produk, perbaikan proses, perancangan peralatan, pengembangan perangkat lunak komputer, sistem telekomunikasi, kapabilitas basis data baru, dan pengembangan dukungan sistem berbantuan komputer.

11. Procurement, terkait dengan fungsi pembelian input yang digunakan dalam value chain organisasi.

\subsection{Portfolio Application}

Tidak seperti pada model konsep traditional portfolio yang hanya mempertemukan hubungan antara sistem aplikasi yang satu dengan yang lainnya, serta bagaimana tugas dan ruang lingkup antar sistem didefinisikan, application portfolio merupakan sebuah model perkiraan kebutuhan sistem aplikasi yang didasarkan pada kebutuhan bisnis disertai dengan definisi apa dan bagaimana sistem aplikasi tersebut memberikan kontribusinya terhadap usaha-usaha pencapaian tujuan bisnis organisasi.

Tabel 2.1 merupakan matriks application portfolio yang terdiri dari empat kuadran, yaitu strategic, key operational, support dan high potential I (Ward, John and Peppard, Joe, 2002).

Tabel 2.1 Matriks Application Portfolio

\begin{tabular}{|l|l|}
\hline STRATEGIC & HIGH POTENTIAL \\
\hline $\begin{array}{l}\text { Aplikasi-aplikasi kritis } \\
\text { untuk menunjang } \\
\text { perkembangan strategi } \\
\text { bisnis organisasi dimasa } \\
\text { yang akan datang. }\end{array}$ & $\begin{array}{l}\text { Aplikasi-aplikasi yang } \\
\text { mungin dibutuhkan } \\
\text { oleh organisasi untuk } \\
\text { keberhasilan dimasa } \\
\text { yang akan datang, } \\
\text { namun belum dibuktikan }\end{array}$ \\
\hline $\begin{array}{l}\text { Aplikasi-aplikasi masa kini } \\
\text { yang dibutuhkan oleh } \\
\text { organisasi agar dapat } \\
\text { menjalankan } \\
\text { bisnisnya. roda }\end{array}$ & $\begin{array}{l}\text { Aplikasi-aplikasi yang } \\
\text { bersifat valuable tetapi } \\
\text { tidak kritis }\end{array}$ \\
\hline KEY OPERATIONAL & SUPPORT \\
\hline
\end{tabular}

1. Strategic

Berisi aplikasi-aplikasi yang secara kritis dibutuhkan untuk keberhasilan bisnis pada masa yang akan datang. Aplikasi ini dibuat untuk mendukung perubahan dan perkembangan organisasi dan bisnisnya.

2. Key Operational

Berisi aplikasi-aplikasi operasional yang ada saat ini, dan dibutuhkan untuk mendukung operasional organisasi dan lebih bersifat sangat penting agar roda bisnis organisasi dapat berjalan.

3. Support Applications

Berisi aplikasi yang dapat mendukung dan meningkatkan efisiensi bisnis dan efektifitas operasional. 


\section{High Potential}

Berisi aplikasi-aplikasi yang bersifat inovatif yang mungkin dapat memperbesar peluang peningkatan keuntungan dimasa yang akan datang, tapi belum dapat dibuktikan.

\section{Analisis Enterprise Dan Pengemabangan Architecture}

\subsection{Profil Politeknik Piksi Ganesha Bandung}

Pada mulanya, tanggal 17 Juli 1993 di Bandung para Sarjana berinisiatif untuk membuka lembaga pendidikan dengan nama lembaga pendidikan PROGRESS dengan ijin Depdikbud No. 1197/KEP/MS/1994. Kemudian melihat perkembangan yang cukup baik dari banyaknya minat masyarakat untuk mengikuti kursus singkat (training) maka mulai dipikirkan secara matang dengan komitmen yang tinggi untuk terus meningkatkan kualitas pendidikan dan peluang kerja bagi para lulusan, maka sejak tanggal 15 Desember 1997, Lembaga Pendidikan PROGRESS secara formal berganti nama menjadi PIKSI GANESHA yang berada dibawah naungan Yayasan PIKSI GANESHA sesuai dengan Akta Notaris Ny. Martinah Sumarno, SH. No.1 tanggal 17 November 2004.

Banyaknya lulusan yang bekerja dan tenaga Dosen yang berkualitas menjadikan bekal yang sangat berharga dan kemudian menjadi network dalam setiap konsep pemikiran dan pengembangan pendidikan lebih lanjut. Dan Alhamdulillah, kami bersyukur karena dengan petunjuk dan karuniaNya, upaya dari semua pihak mulai dari pengelola, staf, dosen, mitra verja, mahasiswa dan alumni, akhirnya terhitung sejak 5 Januari 2004 telah secara resmi menjadi Perguruan Tinggi dengan nama Politeknik Piksi Ganesha sesuai dengan surat keputusan Mentri Pendidikan Nasional Republik Indonesia (MENDIKNAS RI) Nomor 04/D/O/2004 tanggal 4 Januari 2004.

Dengan demikian tanggal 5 Januari 2004 merupakan tanggal berdirinya Politeknik Piksi Ganesha sekaligus merupakan hari jadi, hari kebanggaan dan hari bersejarah bagi Civitas Academika Politeknik Piksi Ganesha.

\subsection{Inisiasi Perencanaan}

Dalam pendekatan metodologi penelitian dalam menyusun perencanaan arsitektur enterprise di Politeknik Piksi Ganesha penelitian ini terdiri dari metodologi EAP yang terdiri dari tahapan sebagai berikut:

1. Inisiasi perencanaan;

2. Model bisnis dan teknologi saat ini;

3. Arsitektur data, aplikasi dan teknologi;

4. Implementasi

\subsection{Area Bisnis}

Politeknik Piksi Ganesha Bandung sebagai perguruan tinggi memiliki aktivitas utama yang berpedoman pada tri dharma perguruan tinggi yang mencakup pendidikan, penelitian dan pengabdian pada masyarakat, aktivitas utama ini akan memerlukan dukungan dari aktivitas lainnya seperti keuangan, administrasi umum, sumber daya manusia. Identifikasi aktivitas utama dan pendukung dari Politeknik Piksi Ganesha Bandung dapat ditunjukan dengan menggunakan rantai nilai (value chain) dari Michael E. Porter yang tampak seperti di bawah ini :

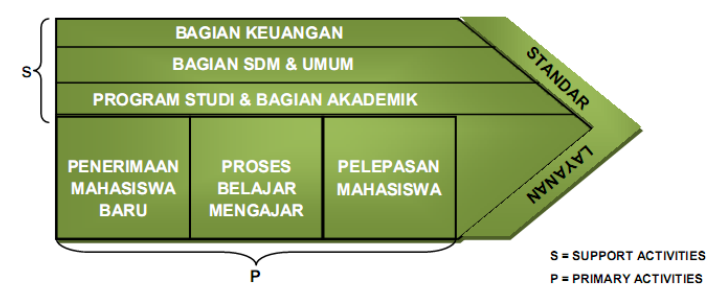

Gambar 3.1 Value Chain Poiiteknik Piksi Ganesha Bandung

\subsection{Arsitektur Sistem dan Teknologi Saat ini}

Usaha-usaha yang dilakukan pada tahap ini untuk memperoleh gambaran kondisi organisasi dalam pemanfaatan SI dan teknologi yang sedang berjalan. Beberapa usaha yang dilakukan adalah sebagai berikut :

\section{Preparasi Koleksi Data}

Politeknik Piksi Ganesha Bandung telah memanfaatkan SI dalam mendukung aktivitas bisnisnya, tetapi belum semua aktivitas telah didukung oleh sistem informasi. Oleh karena itu perlu dilakukan inventarisasi terhadap aplikasi, data dan teknologi yang ada dalam lingkungan organisasi ini. Sistem yang berjalan saat adalah SISFO-PIKSI (Sistem Informasi Politeknik Piksi Ganesha) yang mulai digunakan pada tahun 2008, SISFO-PIKSI merupakan sistem informasi yang dibangun dan dikembangkan untuk menangani dan membantu aktivitas utama dan pendukungnya.

Sistem ini akan dikembangkan secara terintegrasi secara lokal (intranet) maupun terhubung dengan jaringan internet (global connectivity). SISFO-PIKSI menangani data-data yang berhubungan dengan :

1. Aktivitas Utama Organisasi yang menangani data-data yang berhubungan dengan pengelolaan data-data mahasiswa dan akademik berkaitan dengan data:

a. induk mahasiswa,

b. nilai,

c. mata kuliah yang pernah diambil,

d. status mahasiswa,

e. dosen,

f. jadwal

Akses dapat dilakukan oleh unsur direktur, ketua program studi, dosen maupun oleh mahasiswa sendiri sesuai dengan tingkat akses yang diberikan.

2. Aktivitas Pendukung Organisasi yang menangani data-data yang berhubungan dengan :

a. Pembayaran uang kuliah,

b. Status pembayaran

c. Personalia 
Unit organisasi yang telah memanfaatkan sistem ini adalah :
a. Direktur
b. Para Pembantu Direktur
c. Ketua Program Studi
d. Dosen
e. Staf Akademik

f. Kepala Sub Bagian SDM dan Umum

g. Kepala Laboratorium Komputer

h. Kepala Perpustakaan

Araitektur dari SISFO-PIKSI seperti gambar dibawah ini :

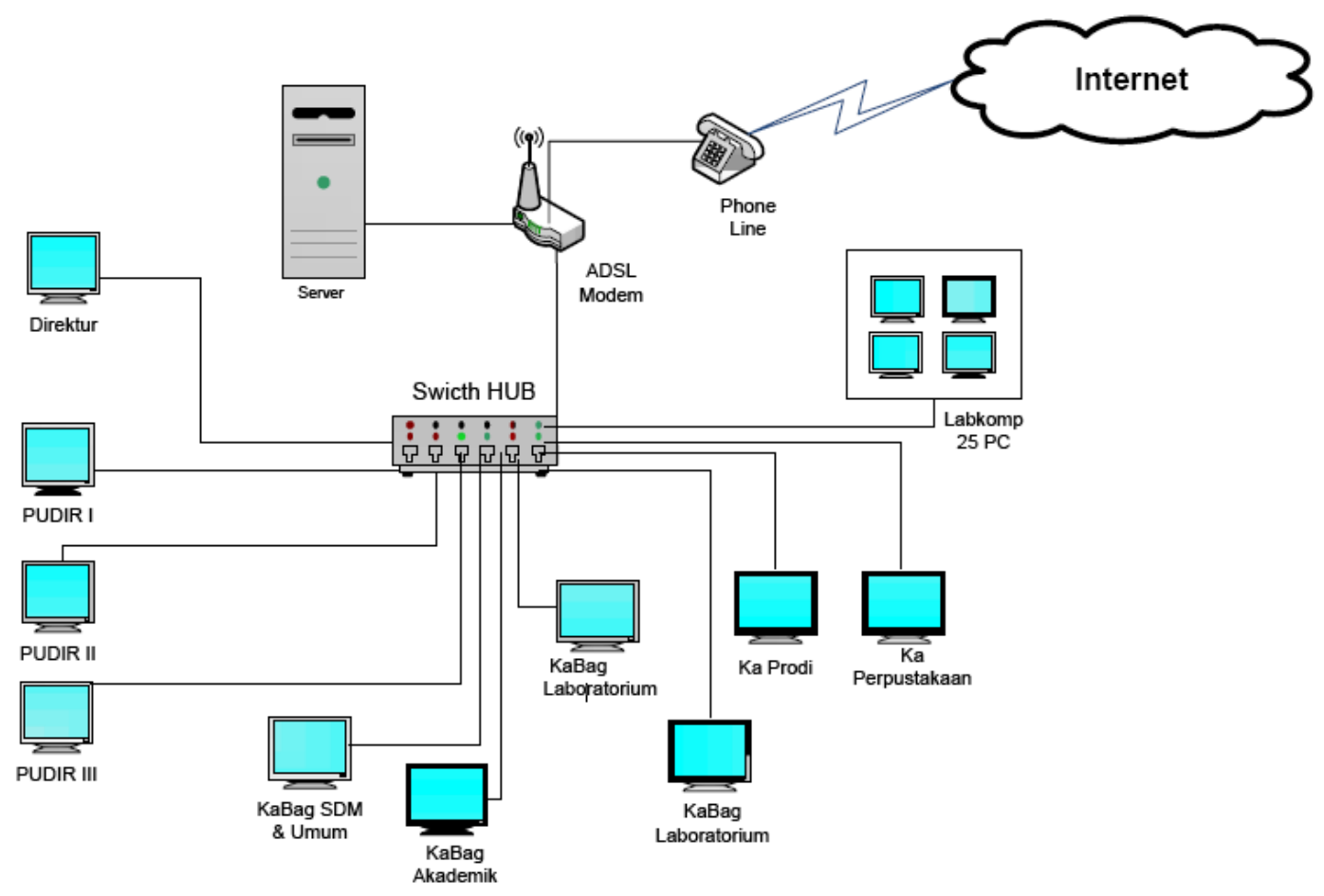

Gambar 3.2 Arsitektur SISFO-PIKSI

\subsection{Arsitektur Aplikasi}

Tabel 3.1 Application Portfolio Politeknik Piksi Ganesha

\begin{tabular}{|l|l|}
\hline STRATEGIC & HIGH POTENTIAL \\
APLICATION & APPLICATION \\
\hline Analisis PMB & Pendaftaran Calon \\
Penyusunan Anggaran & Mahasiswa Baru on \\
PMB & line \\
Analisis Anggaran & Perpustakaan on line \\
Analisis Keuangan & Sistem Informasi \\
Analisis PBM & Akademik on line \\
Manajemen Kurikulum & Sistem Informasi \\
Administrasi Alumni & Akademik Mobile \\
Pelaporan Akademik & E-Learning \\
Manajemen Anggaran & \\
Penerimaan dan & \\
Belanja Organisasi & \\
(APBO) & \\
Manajemen Aktiva & \\
Pelaporan Anggaran & \\
Laporan Keuangan & \\
Pengawasan dan & \\
Evaluasi Kinerja SDM & \\
Pengembangan Skill & \\
dan Pengetahuan & \\
Pelaporan SDM & \\
\hline Administrasi Cuti & Manajemen Sumber \\
\hline
\end{tabular}

\begin{tabular}{|l|l|}
\hline Akademik & Daya Manusia \\
Administrasi & Manajemen Aset \\
Kemahasiswaan & Organisasi \\
Administrasi PBM & Pelaporan Aset \\
Administrasi Seminar & Organisasi \\
PKL & Manajemen \\
Administrasi Sidang TA & Penerimaan Kas \\
Administrasi Ujian & Manajemen Alat Tulis \\
(UTS/UAS) & Kantor (ATK) \\
Manajemen Perwalian & Pelaporan ATK \\
Pembuatan Transkrip & Pengelolaan \\
Nilai & Transaksi \\
Pembuatan ljazah & Penjurnalan \\
Pendaftaran Calon & Neraca Saldo \\
Mahasiswa Baru & \\
Penetapan Status & \\
Mahasiswa & \\
Pengolahan Hasil TKU & \\
Penyusunan Jadwal & \\
Mata Kuliah & \\
Penyusunan Kalender & \\
Akademik & \\
Registrasi Mahasiswa & \\
Baru & \\
Rencana Studi dan & \\
FRS & \\
Seleksi Tes & \\
Kemampuan Umum & \\
(TKU) & \\
\hline
\end{tabular}




\begin{tabular}{|l|l|}
\hline KEY OPERATIONAL & SUPPORT \\
APPLICATION & APPLICATION \\
\hline Keterangan : \\
Aplikasi yang sudah ada \\
Aplikasi yang direncanakan \\
Aplikasi dalam proses pengembangan \\
Aplikasi yang potensial untuk dibuat \\
\hline
\end{tabular}

Tabel 3.2 Kandidat aplikasi Berdasarkan Status

\begin{tabular}{|c|c|}
\hline STATUS & APLIKASI \\
\hline $\begin{array}{l}\text { Aplikasi yang } \\
\text { sudah ada }\end{array}$ & $\begin{array}{l}\text { 1. Administrasi Alumni } \\
\text { 2. Pelaporan Akademik } \\
\text { 3. Laporan Keuangan } \\
\text { 4. Administrasi Cuti } \\
\text { Akademik } \\
\text { 5. Administrasi PBM } \\
\text { 6. Manajemen Perwalian } \\
\text { 7. Pembuatan Transkrip } \\
\text { Nilai } \\
\text { 8. Pendaftaran Calon } \\
\text { 9ahasiswa Baru } \\
\text { 9. Penetapan Status } \\
\text { Mahasiswa } \\
\text { 10. Penyusunan Jadwal } \\
\text { Mata Kuliah } \\
\text { 11. Registrasi Mahasiswa } \\
\text { Baru } \\
\text { 12. Rencana Studi dan FRS } \\
\text { 13. Pelaporan Aset } \\
\text { Organisasi } \\
\text { 14. Manajemen Penerimaan } \\
\text { Kas } \\
\text { 15. Pelaporan ATK } \\
\text { 16. Pengelolaan Transaksi } \\
\text { 17. Sistem Informasi } \\
\text { Akademik Online }\end{array}$ \\
\hline $\begin{array}{l}\text { Aplikasi dalam } \\
\text { proses } \\
\text { Pengembangan }\end{array}$ & $\begin{array}{l}\text { 18. Pendaftaran Calon } \\
\text { Mahasiswa Baru On Line } \\
\text { 19. Perpustakaan On Line } \\
\text { 20. Pelaporan SDM }\end{array}$ \\
\hline $\begin{array}{l}\text { Aplikasi yang } \\
\text { direncanakan }\end{array}$ & $\begin{array}{l}\text { 21. Pelaporan Anggaran } \\
\text { 22. Pengembangan Skill dan } \\
\text { Pengetahuan } \\
\text { 23. Pembuatan ljazah } \\
\text { 24. Penyusunan Kalender } \\
\text { Akademik }\end{array}$ \\
\hline $\begin{array}{l}\text { Aplikasi yang } \\
\text { potensial untuk } \\
\text { dikembangkan }\end{array}$ & $\begin{array}{l}\text { 25. Analisis PMB } \\
\text { 26. Penyusunan Anggaran } \\
\text { PMB } \\
\text { 27. Analisis Anggaran } \\
\text { 28. Analisis Keuangan } \\
\text { 29. Analisis PBM } \\
\text { 30. Manajemen Kurikulum } \\
\text { 31. Manajemen APBO } \\
\text { 32. Manajemen Aktiva } \\
\text { 33. Pengawasan dan } \\
\text { Evaluasi Kinerja SDM } \\
\text { 34. Administrasi } \\
\text { Kemahasiswaan } \\
\text { 35. Administrasi PKL } \\
\text { 36. Administrasi TA }\end{array}$ \\
\hline
\end{tabular}

\begin{tabular}{|l|l|}
\hline 37. Administrasi Ujian \\
(UTS/UAS) \\
38. Pengolahan Hasil TKU \\
39. Seleksi Tes Kemampuan \\
Umum (TKU) \\
40. Sistem Informasi \\
Akademik Mobile \\
41. E-learning \\
42. Manajemen Aset \\
$\begin{array}{l}\text { 43. Organisasi } \\
\text { 44. Manajemen SDM } \\
\text { Tulis Kantor) }\end{array}$ \\
45. Penjurnalan \\
46. Neraca Saldo
\end{tabular}

Tabel 3.3 Kandidat Aplikasi Berdasarkan Fungsi Bisnis

\begin{tabular}{|c|c|}
\hline $\begin{array}{l}\text { FUNGSI } \\
\text { RISNIS }\end{array}$ & KANDIDAT APLIKASI \\
\hline $\begin{array}{l}\text { Penerimaan } \\
\text { Mahasiswa } \\
\text { Baru }\end{array}$ & $\begin{array}{ll}\text { 1. } & \text { Analisis PMB } \\
\text { 2. } & \text { Penyusunan Anggaran } \\
& \text { PMB }\end{array}$ \\
\hline $\begin{array}{l}\text { Proses Belajar } \\
\text { Mengajar/Prodi } \\
\text { dan Bagian } \\
\text { Akademik }\end{array}$ & $\begin{array}{ll}\text { 3. } & \text { Sistem Aplikasi } \\
\text { 4kademik Mobile } \\
\text { 4. } & \text { Pembuatan ljazah } \\
\text { 5. } & \text { Penyusunan Kalender } \\
\text { 6. } & \text { Akademik } \\
\text { 7. } & \text { Administrasi PBM } \\
\text { 8. } & \text { Pelapemen Kurikulum Akademik } \\
\text { 9. } & \text { Administrasi PKL dan } \\
\text { 10. } & \text { Sidang TA } \\
\text { 10erpustakaan On Line }\end{array}$ \\
\hline $\begin{array}{l}\text { Manajemen } \\
\text { Keuangan }\end{array}$ & $\begin{array}{ll}\text { 11. } & \text { Pelaporan Anggaran } \\
\text { 12. } & \text { Analisis Anggaran } \\
\text { 13. } & \text { Analisis Keuangan } \\
\text { 14. } & \text { Manajemen APBO } \\
\end{array}$ \\
\hline $\begin{array}{l}\text { Sub Bagian } \\
\text { SDM dan } \\
\text { Umum }\end{array}$ & 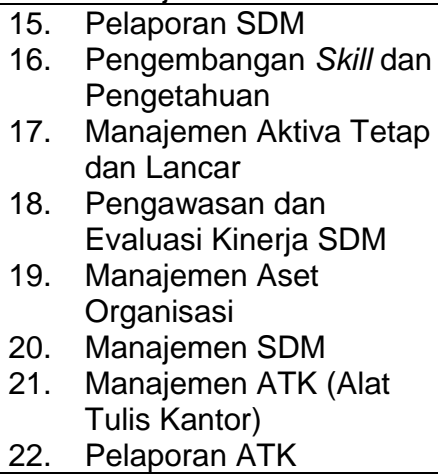 \\
\hline
\end{tabular}




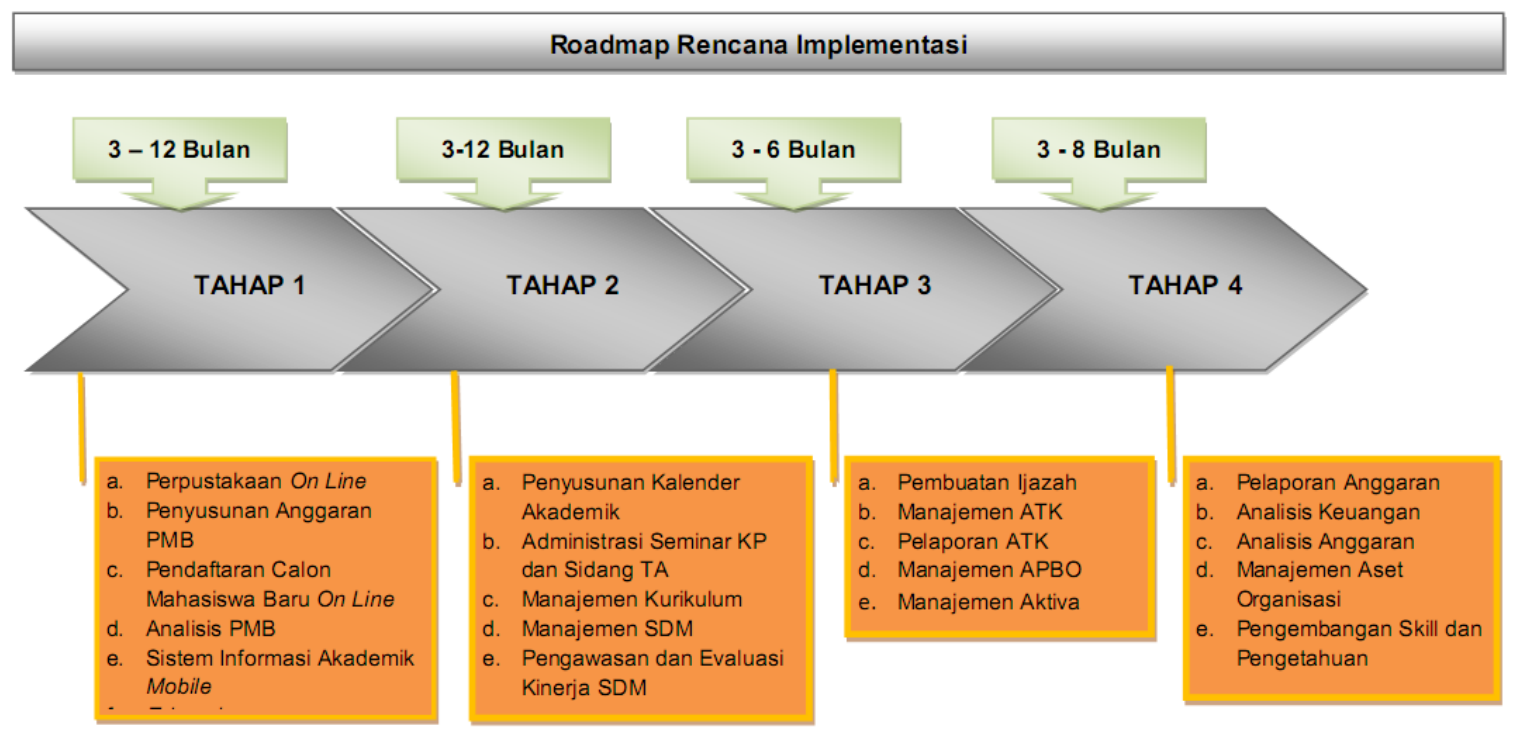

\section{DAFTAR PUSTAKA}

1. Electronic Industry Association, http://www.cio.gov.bc.ca/other/daf/IRM_Gossa ry.htm, Maret 2008

2. $\mathrm{ICH}$ Architecture Resource Center, http://www.ichnet.org/glossary.htm, Maret 2008

3. IBM, Business System Planning (Information System Planning Guide), International Business Machines Corporation, 1981.

4. Krisdanto Suhendro, Perancangan Model Enterprise Architecture dengan Togaf, Juni 2009

5. Sholiq, Analisis Pemodelan Sistem Informasi Berorientasi Objek Dengan UML, 2008
6. Software Engineering Institute, www.sei.org, April 2008

7. Spewak, Steven H,.Steven C.Hill, (1992). Enterprise Architecture Planning : Developing a Blueprint of Data Application and Technology, John Wiley and Sons, Inc.

8. Porter, Michael E, Competitive Advantage : Creating and Sustaining Superior Performance for Analyzing Industries and Competitor, 1985

9. Riverton Coprporation, http://www.riverton.com, Architecture Practice, Maret 2008

10. Ward, John and Peppard, Joe., Strategic Planning for Information System, John Wiley \& Sons, Inc., 2002. 